\title{
DINAMIKA DUKUNGAN SOSIAL BAGI ORANG DENGAN HIV/AIDS
}

\author{
Rahmatika Kurnia Romadhani ${ }^{1}$ dan Hadi Sutarmanto ${ }^{2}$ \\ ${ }^{1}$ Fakultas Ilmu Pendidikan Universitas Negeri Yogyakarta \\ ${ }^{2}$ Fakultas Psikologi Universitas Gadjah Mada Yogyakarta \\ email: rahmatika@uny.ac.id
}

\begin{abstract}
Abstrak: Dinamika Dukungan Sosial bagi Orang dengan HIV/AIDS. Penelitian ini bertujuan mengetahui makna dan bentuk peran dukungan sosial yang diperlukan oleh orang dengan HIV/AIDS. Penelitian ini melibatkan tiga subjek primer dan tiga significant others. Subjek primer dari penelitian ini adalah orang dengan HIV/AIDS (ODHA) Waria dengan sumber terinfeksi hubungan seksual yang tidak aman, dan berganti-ganti pasangan. Subjek berikutnya ialah ODHA dengan sumber terinfeksi penyalahgunaan jarum suntik, serta satu subjek seorang ibu rumah tangga yang tertular virus HIV dari suaminya yang gemar membuat tatto di tubuhnya. Metode yang digunakan dalam penelitian ini adalah kualitatif Interpretative Phenomenological Analysis. Dari penelitian ini ditemukan bahwa dukungan sosial dimaknai sebagai motivasi, pendorong untuk terus semangat menjalani hidup. Dukungan sosial yang diterima membuat subjek lebih optimis dalam menjalani hidup, dan tahu kemana harus meminta pertolongan saat membutuhkan. Dukungan yang paling dibutuhkan adalah seseorang yang mau mendengarkan dan memahami tanpa berprasangka dan membedakan, rasa aman serta rasa dihargai. Kebutuhan lain yang diperlukan adalah kebutuhan instrumental seperti kebutuhan finansial dan kebutuhan akan informasi terkait dengan HIV/AIDS.
\end{abstract}

Kata kunci: HIV/AIDS, ODHA, dukungan Sosial

\begin{abstract}
Dynamic of Social Support among People Living with HIV/AIDS. Social Support Dynamics for People with HIV/AIDS. This study was aimed at determining the meaning and form of the role of social support needed by people with HIV/AIDS. The study involved three primary subjects and three significant others. The primary subjects of this study were People Living with HIV/AIDS (PLWHA), transvestites with an unsafe source of unprotected sexual intercourse, and multiple partners. The next subject was PLWHA with an infected source of needle injection, as well as a subject of a housewife infected with HIV virus from her husband who likes to make tattoos on her body. The method used in this research was Qualitative Interpretative Phenomenological Analysis. The result shows that social support is interpreted as a motivation to continue the spirit of life. Accepted social support makes the subject more optimistic in life, and knows where to ask for help when in need. The most needed support is someone who is willing to listen and understand without prejudice and differentiation, sense of security and sense of respect. Other necessary requirements are instrumental needs such as financial needs and the need for information related to HIV/AIDS.
\end{abstract}

Keywords: HIV/AIDS, PLWHA, Social support 


\section{PENDAHULUAN}

Berdasarkan Peraturan Menteri Kesehatan RI Nomor 21 Tahun 2013 tentang Penanggulanan HIV dan AIDS, Acquired Immunodeficiency Syndrome atau Acquired Immune Deficiency Syndrome atau yang biasa disebut AIDS merupakan gejala rusaknya sistem kekebalan tubuh yang diakibatkan oleh virus yang disebut Human Immunodeficiency atau yang lebih dikenal dengan HIV. Seseorang yang terkontaminasi virus HIV akan rentan terserang penyakit, karena virus ini bekerja dengan melemahkan sistem imun. Hal yang menjadi salah satu ciri terkontaminasi virus ini adalah mudahnya terkena infeksi oportunistik seperti tumor, kuman, dan jamur.

Seseorang dengan HIV/AIDS disebut dengan ODHA (orang dengan HIV/AIDS) (Permenkes RI Nomor 21 Tahun 2013). Sampai saat ini HIV/AIDS merupakan jenis penyakit yang belum bisa disembuhkan, tetapi ada jenis obat antiretroviral (ARV) yang bekerja dengan menekan perkembangan virus. Obat tersebut harus diminum setiap hari secara rutin. HIV umumnya ditularkan melalui cairan tubuh penderita HIV, seperti darah, air mani, cairan vagina, dan air susu ibu. Penularan sendiri dapat terjadi melalui jarum suntik yang tidak steril, hubungan seks yang tidak aman, transfusi darah yang telah terkontaminasi virus HIV, serta turunan dari ibu yang positif HIV/AIDS (Kalalo, Tjitrosantoso, \& Goenawi, 2011).

Dilihat dari jenis dan media perantara perkembangan virus ini, kelompok berisiko untuk HIV/AIDS adalah pengguna napza yang menggunakan jarum suntik, Pekerja Seks Komersial, waria, dan lelaki seks lelaki yang bergantiganti pasangan. Namun, ditemukan juga penderita HIV/AIDS yang tidak termasuk dalam kelompok berisiko, di antaranya adalah ibu rumah tangga dan anakanak. HIV/AIDS di Indonesia pertama kali ditemukan pada tahun 1984 di Bali. Sampai saat ini HIV/AIDS telah menyebar di seluruh negeri termasuk Yogyakarta. Tercatat sampai dengan Juni 2013 jumlah ODHA di DIY mencapai 2168 berdasar data dari Komisi penanggulangan AIDS (2013).

Sejauh ini masyarakat masih memiliki anggapan negatif terhadap orang dengan HIV/AIDS. Banyak stigma yang melekat bagi ODHA. UNAIDS (2011) mendefiniskan stigma dan diskriminasi terkait dengan HIV sebagai ciri negatif yang diberikan pada seseorang sehingga menyebabkan tindakan yang tidak wajar dan tidak adil terhadap orang tersebut berdasarkan status HIV-nya. HIV/AIDS dianggap sebagai penyakit kutukan akibat dari perbuatan buruk seperti seks bebas atau penyalahgunaan narkoba. Selain itu, berdekatan dan berinteraksi dengan ODHA masih dianggap dapat menularkan virus HIV sehingga banyak orang enggan untuk berhubungan dan berinteraksi dengan ODHA. Hal tersebut tidak saja dilakukan oleh masyarakat pada umumnya, tetapi dari kalangan medis pun masih menunjukkan perilaku diskriminatif terhadap ODHA.

Diskriminasi, stigma, ketakutan, dan keputusasaan adalah hal lain yang harus dihadapi ODHA, selain beban fisik yang harus ditanggung. Ketika menghadapi diskriminasi sosial dari lingkungan, diperlukan suatu mekanisme pertahanan yang kuat. Salah satu mekanisme pertahanan yang baik menurut Bor, Miller, dan Goldman (1993) adalah dukungan sosial yang kuat. Sebuah studi di Thailand mengungkapkan dalam sebuah keluarga yang terinfeksi HIV/AIDS, 
anggota keluarga lainnya merupakan pendukung terbaik dari segi psikologis dan ekonomis (Manopaiboon, Shaffer, \& Clark, 1998). Tidak adanya dukungan terhadap anggota keluarga dengan HIV/ AIDS disinyalir menjadi dampak konflik keluarga (Castro, Orozco, Eroza, Manca, Hernandez, \& Aggleton, 1998). Dukungan keluarga juga dapat membawa efek positif bagi psychological well being ODHA (Ostrow, Monjan, Joseph, VanRaden, \& Fox, 1989). Selain keluarga, dukungan sosial dari pihak-pihak lain juga menjadi faktor pendukung bagi ODHA untuk bisa terus berjuang hidup dengan baik.

HIV/AIDS merupakan virus yang menyerang kekebalan tubuh, dimana kekebalan tubuh berkaitan pula dengan kondisi psikologis. Salah satu faktor yang menjadi masalah pada orang dengan HIV/AIDS adalah minimnya dukungan sosial yang diberikan oleh keluarga dan lingkungan. Berdasarkan paparan di atas, dukungan sosial adalah salah satu hal yang dapat meningkatkan self esteem bagi seseorang. Dengan self esteem yang cukup, seseorang akan lebih yakin menghadapi segala permasalahan yang akan ditemuinya sehingga respons yang akan muncul adalah keyakinan bahwa dirinya bisa melalui permasalahan tersebut. Selain itu, dengan adanya dukungan sosial, individu akan merasa aman bahwa ada orang lain yang mau membantu ketika dirinya mengalami kesulitan. Hal sebaliknya ditemukan bahwa orang dengan dukungan sosial yang minim, merespons masalah yang dihadapi dengan negatif, lebih merasa tidak berdaya dalam menghadapi masalah yang menimpa. Ketika rasa ketidakberdayaan yang muncul, hal tersebut akan diikuti dengan reaksi fisik yang juga negatif, di antaranya adalah depresi dan psikosomatis. Hal tersebut memiliki dampak negatif terhadap kondisi kesehatan orang dengan HIV/ AIDS.

Berdasarkan pemaparan tersebut, penelitian ini bertujuan untuk mengetahui (1) orang dengan HIV AIDS memaknai dukungan sosial, (2) peran dukungan sosial terhadap kehidupan ODHA, dan (3) dukungan sosial seperti yang dibutuhkan oleh ODHA. Diharapkan dari penelitian ini dapat membantu ODHA sesuai dengan yang dibutuhkan oleh ODHA.

\section{METODE}

Pengambilan subjek dalam penelitian ini menggunakan teknik purposive sampling. Subjek dipilih berdasarkan kesesuaian diri dengan kriteria dalam permasalahan penelitian (Poerwandari, 2005). Oleh karena itu, penelitian ini mengambil subjek yang memiliki ciriciri sebagai berikut: (1) memiliki status HIV Positif penggunaan narkotika jarum suntik, hubungan seks bergantiganti pasangan maupun terinfeksi dari pasangan hidup; (2) subjek berdomisili di Daerah Istimewa Yogyakarta; dan (3) laki-laki, perempuan atau waria berusia antara 35 hingga 55 tahun. Menurut Santrock (2012) usia tersebut merupakan usia dewasa tengah. Pada tahap usia tersebut terjadi proses evaluasi atas kehidupan yang telah dijalani.

Untuk mengumpulkan data dalam penelitian kualitatif ini, diperlukan metode yang tidak membatasi subjek dalam mengungkapkan sudut pandangnya. Metode yang dipandang tepat untuk memenuhi kriteria tersebut adalah dengan menggunakan metode wawancara. Pada penelitian ini, jenis wawancara yang digunakan adalah wawancara semi terstruktur.

Untuk memeriksa kredibilitas dari penelitian ini, digunakan teknik 
triangulasi (Moleong, 2012). Penelitian ini menggunakan teknik triangulasi waktu, data, dan metode. Berdasarkan tujuan yang telah ditetapkan maka teknik analisis yang digunakan adalah Interpretative Pheno-menological Analysis (IPA). Pendekatan Interpretative Phenomenological Analysis (IPA) ini memiliki beberapa langkah yaitu sebagai berikut.

Reading Re-reading. Pada tahap ini, peneliti menenggelamkan diri pada catatan yang telah didapatkan saat pengambilan data. Proses ini mencakup mendengarkan ulang rekaman wawancara yang telah dilakukan, kemudian membaca hasil asli dari wawancara tersebut. Tahap ini juga bertujuan untuk mengurangi kesalahan pemahaman peneliti dalam menganalisis pengalaman subjek.

Initial Noting. Pada tahap ini dilakukan proses penjelasan konten semantik dan penggunaan bahasa pada data yang telah didapat. Proses analisis ini mencakup pemberian komentar terhadap hal-hal menarik yang ditemukan pada data penelitian. Komentar eksploratori ini mencakup komentar deskriptif (descriptive comment), komentar bahasa (linguistic comment), dan komentar konseptual (conceptual comment).

Developing Emergent Themes. Langkah selanjutnya adalah mengembangkan tema-tema yang muncul dari transkrip asli. Untuk memunculkan tema-tema, peneliti mengelola perubahan data dengan melakukan analisis secara simultan, berusaha mengurangi volume catatan yang kompleks untuk dicari keterkaitannya dan mencari pola-pola yang muncul.

Searching Connection a cross Emergent Themes. Langkah ini dilakukan setelah peneliti menemukan tema-tema yang muncul dalam data penelitian. Peneliti kemudian menyusun tema-tema yang muncul dalam suatu urutan kronologis. Tema-tema tersebut kemudian dipetakan dan dikelompokkan berdasarkan kesesuaian tema. Tema yang akan diangkat disesuaikan dengan pertanyaan yang diajukan dalam penelitian ini.

Setelah tema-tema muncul, dikelompokkan, dan diurutkan secara kronologis, maka langkah selanjutnya adalah mencari makna dari tematema tersebut. Proses penghubungan antartema tersebut dapat dilakukan dengan beberapa cara di antaranya: abstraksi, subsumtion, polarization, contextualization, dan numeration.

Moving to The Next Cases. Tahap 1 sampai dengan 4 dilaksanakan pada setiap subjek. Setelah satu kasus selesai, berpindah pada subjek selanjutnya dan mengulangi keseluruhan proses yang telah dilakukan hingga selesai untuk seluruh subjek.

Looking for Patterns a Cross Cases. Tahap terakhir dalam proses analisis ini adalah dengan mencari pola yang muncul antarsubjek. Pada tahap ini dilakukan dengan membuat tabel yang mencakup perbandingan temuan antarsubjek.

\section{HASIL DAN PEMBAHASAN}

Hasil penelitian disajikan pada Tabel 1 yang memuat perbandingan temuan antarsubjek.

\section{Kondisi Fisik dan Psikologis}

Ketiga subjek penelitian adalah orang dengan HIV/AIDS dengan sumber terinfeksi yang berbeda. Hal tersebut sesuai dengan apa yang disampaikan Latief (2005) bahwa sebagian besar penularan HIV/AIDS melalui hubungan yang bersifat heteroseks (bergantiganti pasangan), kemudian diikuti oleh para pengguna narkoba jarum suntik. 


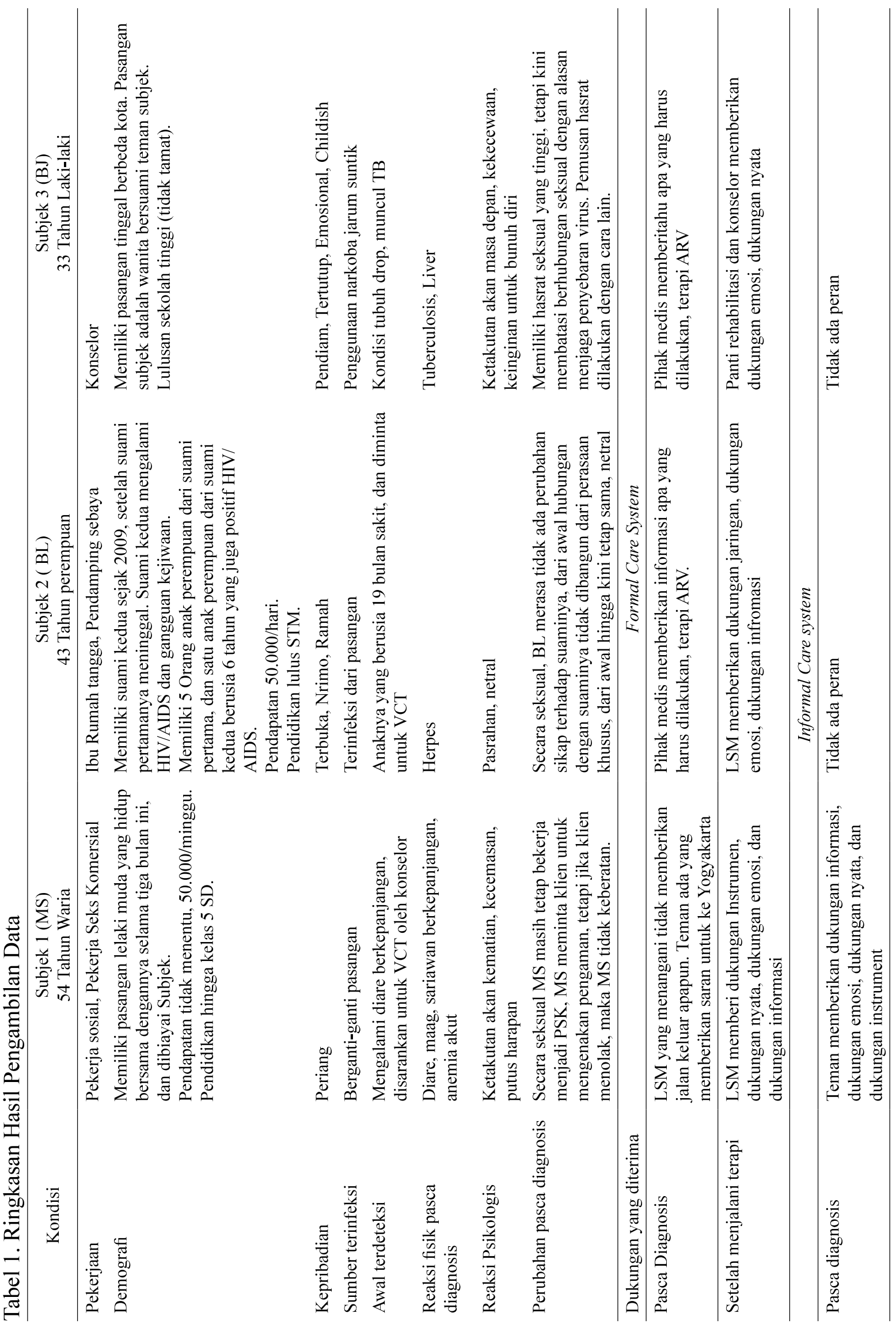




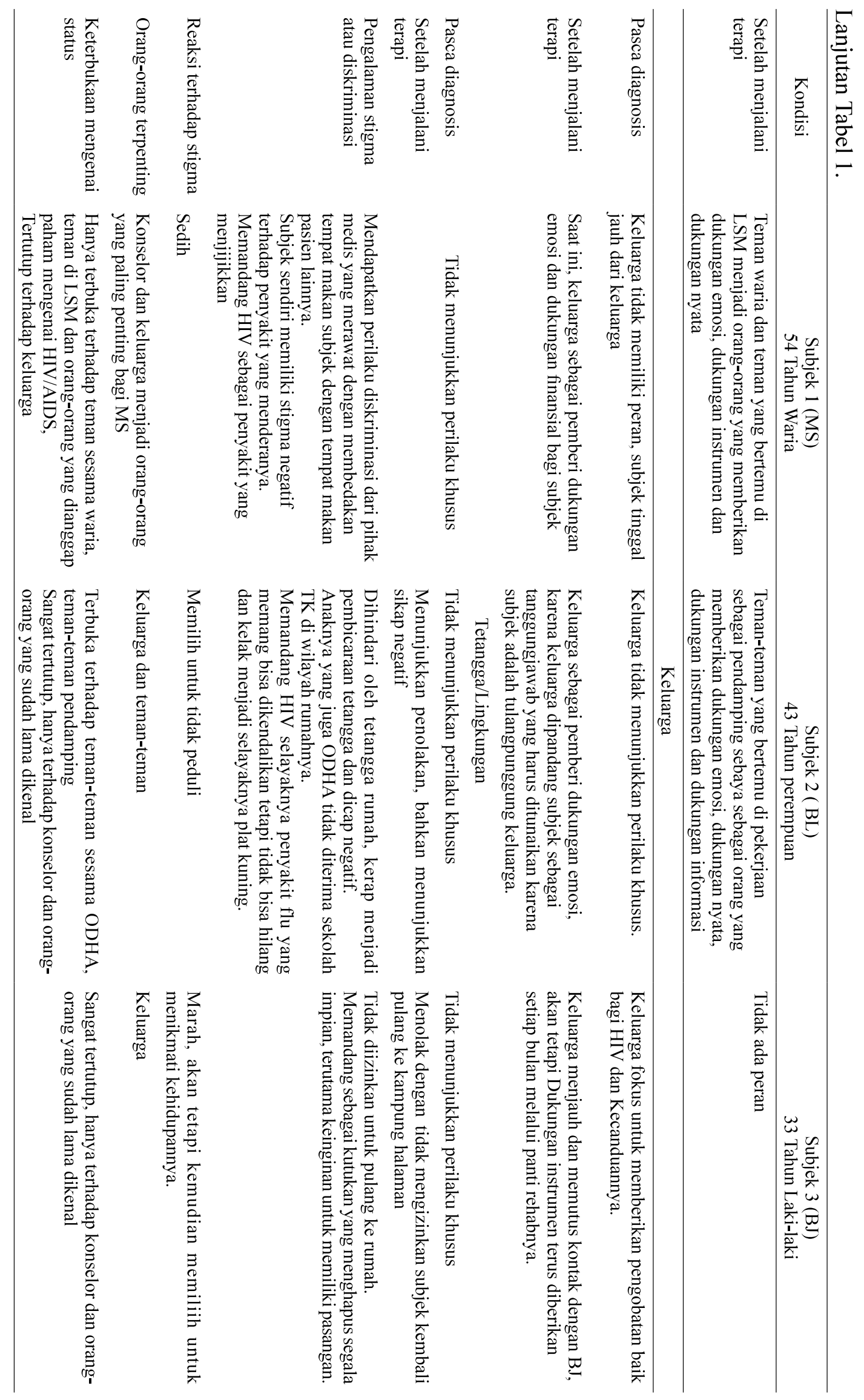


Homoseks, pekerja seks komersial (PSK), pelanggan PSK, waria, dan pelanggan waria.

Sebelum melakukan terapi ARV, dua subjek mengatakan sudah pernah mengalami infeksi oportunistik. Menurut Seligson dan Peterson (1992), hal ini diakibatkan oleh virus yang telah menyerang tubuh. Ketika virus telah menginfeksi tubuh, hal yang kemudian akan muncul adalah infeksi oportunistik. Infeksi oportunistik merupakan penyakitpenyakit ringan yang pada dasarnya mudah untuk diatasi, tetapi karena daya tahan tubuh yang tidak lagi baik sehingga penyakit tersebut menjadi sulit diatasi dan bisa menimbulkan kematian (Seligson \& Peterson, 1992).

Infeksi oportunistik yang muncul juga merupakan tanda bahwa subjek telah mencapai level AIDS. Waktu perkembangan dari HIV menuju AIDS tidak sama antara individu satu dengan yang lain, selain itu tahapan virus dapat dikatakan masuk kategori AIDS ketika jumlah CD4 di bawah 200 per mm3 (Kementrian Kesehatan RI, 2012).

Subjek pertama merasakan ketakutan akan nasibnya, syok, ketakutan akan kemati-an, ketidakpercayaan kenapa harus dirinya, kemudian mengalami rasa marah. Subjek ketiga menunjukkan reaksi kemarahan, ketakutan bahkan menunjukkan upaya untuk bunuh diri. Hal tersebut sesuai dengan yang diungkapkan Feldman (Lambert, 2004) bahwa hal-hal yang kemudian muncul adalah perasaan kebingungan, marah, tidak percaya, merasa dihantui, takut terhadap kematian, takut kepada reaksi orang lain terhadap mereka dan ketakutan akan pemberitaan mengenai dirinya.

Subjek ketiga merasakan bahwa infeksi yang menyerang tubuhnya seketika menghilangkan masa depannya.
Reaksi psikologis yang muncul menurut Coates (dalam Ogden, 2000) merupakan implikasi dari sifat HIV/AIDS yang dapat menimbulkan penyakit bahkan kematian. Subjek kedua belum merasakan penyakit yang ditimbulkan oleh infeksi yang menyerang tubuhnya, sehingga tidak ada rasa kesakitan atau ketakutan seperti yang sudah dirasakan subjek pertama dan subjek kedua.

\section{Reaksi Lingkungan dan Keterbukaan Subjek terhadap Statusnya}

Menurut Derlega, Winstead, Greene, Serovich, dan Elwood (2004) terbuka akan status HIV/AIDS bukan hal mudah. Ketika seorang ODHA membuka diri, tujuan keterbukaannya adalah untuk mencari dukungan, katarsis, dan keinginan untuk memberikan pembelajaran. Menyalahkan diri sendiri, ketakutan ditolak, melindungi diri dan keprivasian adalah alasan ODHA untuk menutupi statusnya. Hal ini ditemukan pada subjek pertama, kedua dan ketiga.

Mawar dan Paranjape (2002) menyatakan bahwa diskriminasi yang muncul di lingkungan dipengaruhi oleh sifat dari HIV/AIDS yang sampai saat ini belum ditemukan obatnya. HIV/AIDS merupakan penyakit yang mengancam kehidupan atau bisa menimbulkan kematian. Masyarakat ketakutan jika tertular HIV/AIDS. Penyakit tersebut diasosiasikan sebagai penyakit akibat perilaku yang tidak baik seperti berhubungan seks sesama jenis dan pengguna narkotika.

\section{Dukungan Sosial yang Diterima}

Keterbukaan yang dilakukan subjek pertama terhadap teman-teman warianya, membuat seorang teman memberitahukan bahwa di Yogyakarta ada LSM yang berkecimpung menangani kesejahteraan waria. Schaefer, Coyne, dan Lazarus 
(1981) menjelaskan bahwa dukungan yang diterima subjek pertama merupakan dukungan jaringan atau bisa termasuk dalam kategori dukungan informasi jika dilihat dari bentuk dukungan sosial Taylor (Taylor, 2006). Memberikan dukungan bahwa ia tidak sendirian dan ada yang bisa membantu.

Ketiga subjek juga merasa bahwa mereka mendapatkan dukungan untuk terus maju, seperti dalam lingkup pekerjaan, pekerjaannya diapresiasi. Taylor (2006) menyatakan bahwa hal tersebut termasuk dalam dukungan penghargaan. Berdasarkan bentuk-bentuk dukungan sosial, ketiga subjek mendapatkan seluruh bentuk dukungan (Taylor, 2006; Schaefer et al., 1981). Hal yang membedakan adalah intensitas dan frekuensi pemberian untuk masing-masing jenis dukungan.

Subjek pertama memaknai dukungan sebagai motivasi yang diberikan oleh orang lain terhadap dirinya. Dukungan yang diterima selama ini, dimaknai oleh subjek pertama sebagai hasil dari perilaku baik yang selama ini Ia tunjukkan. Subjek kedua memaknai dukungan sebagai dorongan untuk tetap bertahan dan pemberian solusi atas apa yang sedang dialaminya. Subjek ketiga memaknai dukungan sebagai pendorong untuk pulih dan bertahan.

Ketiga subjek memaknai dukungan sebagai motivasi atau pendorong untuk tetap bertahan. Hal tersebut serupa dengan definisi dari Cohen, Gottlieb, dan Underwood (2000) yang menyebutkan bahwa dukungan sosial adalah proses interaksi dalam hubungan yang dapat menyediakan coping, esteem, kepemilikan, dan bantuan kemampuan.

Kondisi kesehatan subjek pun kini membaik. Semenjak terakhir masuk rumah sakit pada saat awal pindah ke Jogja sampai saat ini, subjek belum pernah lagi mengalami penurunan kondisi fisik. Kebutuhan yang paling mendasar dan begitu dibutuhkan oleh subjek pertama adalah rasa pasti bahwa ada tempat untuk dirinya meminta tolong ketika dirinya membutuhkan pertolongan, rasa aman, dan rasa dicintai.

Dampak dari dukungan sosial yang telah diterima ketiga subjek membawa pengaruh positif terhadap kehidupan subjek. Hal tersebut dipengaruhi oleh kesesuaian antara kebutuhan subjek dengan yang diberikan oleh lingkungan sekitarnya. Dalam hal ini, subjek pertama dan kedua dipenuhi dukungan sosialnya oleh LSM, teman-teman di LSM, dan keluarga, sedangkan subjek ketiga dipenuhi kebutuhannya oleh Panti Rehabilitas dan keluarga. Hal tersebut memenuhi konsep the matching hypotesis dari Cohen \& McKay, 1984; Cohen \& Wills (Smet, 1994).

Penelitian sebelumnya juga menemukan bahwa ODHA yang mendapatkan dukungan sosial lebih banyak dilaporkan secara signifikan memiliki tingkat depresi yang rendah, dan tidak mengalami banyak masalah. Sementara ODHA dengan dukungan sosial yang rendah lebih rentan depresi dan mengalami masalah lainnya (Lee, Detels, RotheramBorus, \& Duan, 2007). Sun, et al. (2009) mengungkapkan jika kurangnya dukungan sosial dan fungsi keluarga yang minim mengakibatkan rasa kesendirian dan kesepian pada ODHA. Rasa kesepian tersebut mengakibatkan efek psikososial yang negatif sehingga dikatakan bahwa ODHA dengan dukungan sosial yang lebih baik dan mendapatkan perhatian yang cukup dapat mencegah efek negatif psikososial.

Temuan dalam penelitian ini disajikan pada Gambar 1. 
Dinamika Dukungan Sosial...(Rahmatika K.R. dan Hadi S.)

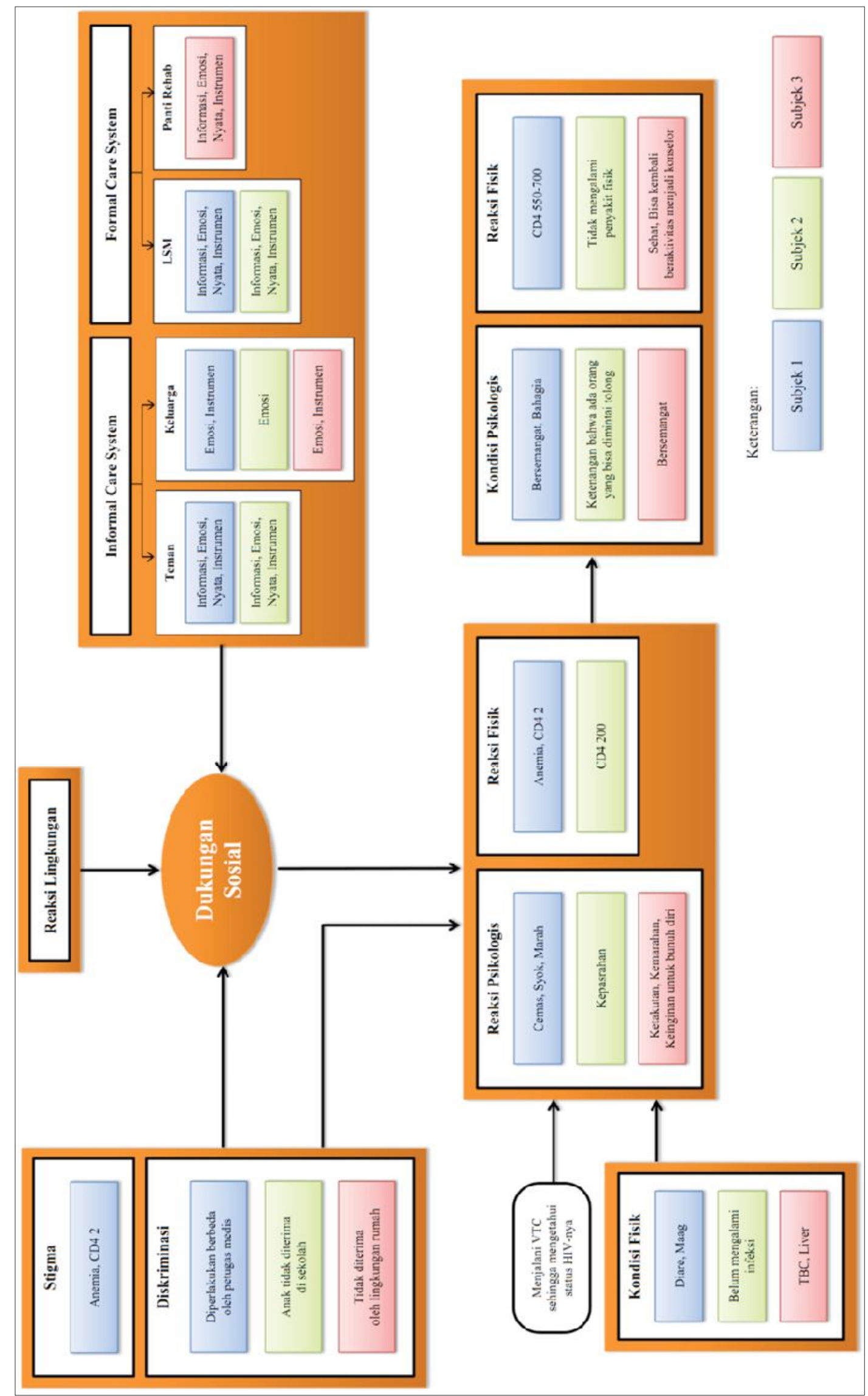

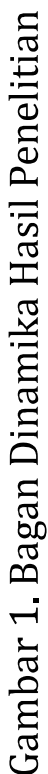




\section{SIMPULAN}

Kesimpulan yang didapat dari penelitian, bahwa dukungan sosial dimaknai sebagai motivasi, dorongan untuk tetap bertahan dengan segala kondisi yang dialami. Hal tersebut didefinisikan sebagai memberikan semangat untuk terus menjalani terapi ARV dengan tepat, memahami apa yang dirasakan, menjadi pendengar dan memberi solusi ketika terjadi masalah. Dukungan sosial yang telah diterima oleh ketiga subjek membuat mereka menjadi lebih bisa menerima akan statusnya sebagai ODHA. Lebih positif dalam menghadapi hidup, dan memandang bahwa ketika terjadi sesuatu dalam hidupnya, tahu siapa dan ke mana mereka harus mencari pertolongan. Rasa positif yang telah diterima dari dukungan yang telah diberikan, kemudian mempengaruhi kondisi fisik dari subjek menjadi lebih sehat. Dukungan sosial berperan sebagai penguat dan penolong. Dukungan yang paling dibutuhkan adalah seseorang yang mau mendengarkan, dan memahami tanpa berprasangka dan membedakan. Selain itu, kebutuhan lain adalah kebutuhan untuk merasa aman dan dihargai. Kebutuhan lain yang diperlukan adalah kebutuhan instrumental seperti kebutuhan finanasial dan kebutuhan akan informasi.

Berdasarkan hasil penelitian diketahui bahwa keluarga bukanlah sumber pendukung utama, keluarga justru dianggap sebagai orang yang dihindari untuk tahu mengenai status HIV, dan menunjukkan penolakan terhadap anggota keluarga dengan HIV/AIDS. Diharapkan keluarga dapat bersikap bijak terhadap anggota keluarga yang berstatus positif HIV/AIDS, karena dukungan keluarga merupakan salah satu factor yang dapat meningkatkan kondisi pasien. Berdasarkan penelitian yang telah dilaksanakan, beban berat yang harus diterima oleh ODHA selain kondisi fisiknya adalah reaksi lingkungan atas status HIV seseorang. HIV/AIDS memang menular dan dapat berakibat mematikan, akan tetapi penginfeksian virus HIV memiliki syaratsyarat tertentu seperti berhubungan seks tanpa pengaman, berbagi jarum suntik atau melalui cairan tubuh seperti ASI, darah, air mani. Namun, HIV tidak menular hanya dengan keringat, air mata, berbagi alat makan atau berpelukan. Yang perlu dilakukan adalah menghindari virusnya, tetapi tidak orangnya sehingga masyarakat tidak menjadi beban kedua bagi ODHA.

Berdasarkan penelitian, terjerumus ke dalam lingkungan yang berisiko HIV/ AIDS salah satunya dipengaruhi oleh lingkungan. Oleh sebab itu, diperlukan upaya preventif untuk menghindarkan anak terjerumus dalam penyalahgunaan obat terlarang, berganti-ganti pasangan seks, dan diperlukan upaya sosialisasi mengenai bahaya penggunaan narkoba dan seks bebas. Psikolog, praktisi pendidikan maupun pekerja sosial dapat melakukan kerja kolaboratif maupun independen terkait dengan upaya tersebut. Sekolah menengah pada khususnya dapat melakukan edukasi dan promosi terkait bahaya narkoba, seks bebas, dan upaya penanggulan HIV/AIDS. Edukasi tersebut dapat berupa penjelasan klasikal oleh guru maupun penggunaan media penunjang, seperti dengan melalui poster, film maupun kegiatan ekstrakurikuler yang relevan.

Lembaga pendidikan juga bisa bekerja sama dengan psikolog melalui program psikolog masuk sekolah. Psikolog dan petugas medis dapat melakukan upaya kolaboratif dengan melakukan sosialisasi mengenai HIV/AIDS, konseling, dan tes VCT pranikah untuk sebagai upaya preventif. Diperlukan pula sosialisasi baik dari psikolog maupun petugas medis mengenai pentingnya menghindari 
virusnya, tetapi tidak dengan menghindari orangnya.

Pada peneliti selanjutnya, diharapkan peneliti dapat memperbanyak waktu dalam menggali data dan melakukan pendekatan dengan subjek penelitian sehingga dapat diperoleh hasil yang lebih maksimal. Pada penelitian ini baru dimunculkan tiga subjek dengan tiga macam penularan, diharapkan penelitian selanjutnya dapat menggali ODHA dengan alasan terinveksi melalui Lelaki seks lelaki dan anak dari orang tua yang positif HIV/ AIDS.

\section{DAFTAR PUSTAKA}

Bor, R., Miller, R., \& Goldman., E. 1993. "HIV/AIDS and The Family: A Review of Research in The First Decade". Journal offamily Therapy, 15, 187-204.

Castro, R., Orozco, E., Eroza, E., Manca, M., Hernandez, J., \& Aggleton, P. 1998. "Family Response to HIV/AIDS in Mexico". AIDS care, 10, 583-598.

Cohen, S., \& Mc.Kay, G. 1984. "Social Support, Stress, and the Buffering Hypothesis: A Theoretical Analysis". Dalam A. Baum, J. E. Singer, \& S. E. Taylor (Eds.), Handbook of Psychology and Health (Vol. 4). Hillsdale, NJ: Erlbaum.

Cohen, S., Gottlieb, B., \& Underwood, L. 2000 . "Social Relationships and Health". Dalam S. Cohen, L. Underwood, \& B. Gottlieb (Eds.), Social Support Measurement and Intervention: A Guide for Health and Social Scientists (pp. 3-25). New York: Oxford University Press.

Derlega, V. J., Winstead, B. A., Greene, K., Serovich, J., \& Elwood, W. N. 2004. "Reasons for HIV Disclosure/ Nondisclosure in Close Relatioship: Testing Model of HIV-Disclosure Decision Making".Journal of Social and Clinical Psychology, 23(6), 747-767.
Kalalo, J. G. K., Tjitrosantoso, H. M. T., \& Goenawi, L. R. 2011. "Studi Penatalaksanaan Terapi pada Penderita HIV/AIDS di Klinik Rumah Sakit Kota Manado". Pharmacon, 1(2), 98-103.

Komisi Penanggulangan AIDS Indonesia. 2013. Data Kasus HIV dan AIDS di DIY 2013. Diunduh dari http://www.kpai. org pada tanggal 8 Desember 2013.

Latief, M. S. 2005. Siapa Peduli AIDS di Yogya?: Kinerja KPAD dan DPRD DIY dalam Penanggulangan HIV/AIDS pada Era Otonomi Daerah. Yogyakarta: Pusat Studi Kependudukan dan Kebijakan, Universitas Gadjah Mada

Lambert, L. 2004. Women, Psychology and HIV/AIDS What Can Be Learned from an Eco-Social Perspective? Proposal for Second International Congress of The Asian Federation for Psychoterapy in Iran. England: University of Wamborough.

Lee, S.J., Detels, R., Rotheram-Borus, M, J., \& Duan, N. 2007. "The Effect of Social Support on Mental and Behavioral Outcomes among Adolescent with Parents with HIV/AIDS". American Journal of Public Health, 97(10).

Manopaiboon, C., Shaffer., \& Clark, L. 1998. "Impact of HIV on Families of HIVinfected Women who Have Recently Given Birth, Bangkok, Thailand". J Acquir immune defic syndrom Hum Retrovirol, 18(1), 54-63.

Mawar, N., \& Paranjape, R. S. 2002. "Live and Let Live: Acceptance of People Living with HIV/AIDS in an Era where Stigma and Discrimination Persist". ICMR Bull, 32, 105-114.

Moleong, L. 2012. Metode Penelitian Kualitatif. Bandung: Remaja Rosdakarya.

Ogden, J. 2000. Health Psychology A Textbook ( $2^{\text {nd }}$ ed.). Philadelphia: Open University Press. 
Ostrow, D., Joshep. J., Van-Raden., \& Lawrence. 1989. "HIV Related Symptoms and Psychological Functioning in A Cohort of Homosexual Men". American Journal of Psychiatry, 146, 737-742.

Permenkes RI Nomor 21 Tahun 2013 tentang Penanggulanan HIV dan AIDS.

Poerwandari, K. 2005. Pendekatan Kualitatif untuk Penelitian Perilaku Manusia. Depok: LPSP3 UI.

Santrock, J. W. 2012. A Topical Approach to Lifespan Development (6 ${ }^{\text {th }}$ ed.). New York: McGraw Hill .

Schaefer. C, Coyne, J. C., \& Lazarus, R. S. 1981. "The Health-Related Function of Social Support". Journal of Behavioral Medicine, 4(4). 381-406.
Seligson, M.R.,\& Karen E,.Peterson. 1992. "AIDS Prevention and Treatment: Hope, Humor, and Healing". New York: Hemisphere Publishing Corporation Smet, B. 1994. Psikologi Kesehatan. Jakarta: Grasindo.

Sun, Y. H., Sun, L., Wu, H. Y., Zhang, Z. K., Wang, B., Yu, C., \& Cao, H. Y. 2009. "Loneliness, Social Support and Family Function of People Living with HIV/AIDS in Anhui Rural Area, China". International Journal of STD \& AIDS, 20, 255. DOI: $10.1258 / \mathrm{ijsa} .2008 .008348$.

Taylor. S. E. 2006. Health Psychology. Boston: McGraw-Hill.

UNAIDS. 2011. Political Declaration on HIV/AIDS. Diunduh dari: www.unaids.org pada tanggal 8 Desember 2013. 